\title{
Determining the Scope of the Local Remedies Rule in UNCLOS Disputes
}

\author{
Loris Marotti
}

\begin{abstract}
Art. 295 of the UN Convention on the Law of the Sea (UNCLOS) embodies the rule of prior exhaustion of local remedies by making a renvoi to cases where the application of the rule is required by international law. In the practice of the International Tribunal for the Law of Sea (ITLOS) and Annex VII Tribunals, States continuously raise preliminary objections based on Art. 295. However, such tribunals have never found the local remedies rule applicable. In this paper, it is argued that the approach taken by UNCLOS Tribunals towards the applicability of the local remedies rule is not persuasive since, absent proper reasoning, it fails to align with - or expressly depart from - what appears to be the present state of international law on the topic. Furthermore, the above practice undermines the effectiveness of Art. 295 and calls into question the actual relevance of the local remedies rule within uncLos disputes. In the present article the approach followed by UNCLOS Tribunals with respect to the applicability of the local remedies rule is assessed against a reconsideration of the issue of mixed claims and the specific regime set forth in the Law of the Sea Convention. In the concluding section the approach taken in UNCLOS Tribunals' case law is considered in light of recent criticisms pointing out the current improper expansion of the jurisdiction under UNCLOS Part XV.
\end{abstract}

\section{Keywords}

Art. 295 UNCLOS - ITLOS - Annex VII Tribunals - Local Remedies Rule - Mixed Claims

Introduction

As in other fields of international law, the rule of prior exhaustion of local remedies is supposed to play a role also in the law of the sea. In this regime, the 
relevance of such 'important principle of customary law'1 is attested by Art. 295 of the UN Convention on the Law of the Sea (UNCLOS or the Convention), whereby

any dispute between States Parties concerning the interpretation or application of this Convention may be submitted to the [compulsory procedures entailing binding decisions] only after local remedies have been exhausted where this is required by international law.

The reference to cases where the exhaustion of local remedies 'is required by international law' means that this provision simply appeals to customary law and does not constitute lex specialis. It 'neither broadens nor narrows the existing rules of international law on the subject'. ${ }^{2}$

Since the entry into function of compulsory procedures entailing binding decisions under UNCLOS, several States in different cases have raised objections of admissibility based on Art. 295. To date, in at least five - out of twenty-five contentious cases the question arose before the International Tribunal for the Law of the Sea (ITLOS or Tribunal), although not always thoroughly addressed. ${ }^{3}$ In two cases, the local remedies rule was invoked and discussed before Annex VII Tribunals. ${ }^{4}$ The total amount of cases in which the application of the local remedies rule was invoked might actually not appear so impressive. However, two caveats are in order in this respect. First, it is generally acknowledged that the exhaustion of local remedies is not required in prompt release proceedings under Art. 292 UnCLOS. ${ }^{5}$ As the ITLOs held in the 'Camouco' judgment, 'it is not logical to read the requirement of exhaustion of local remedies or

1 Elettronica Sicula SpA (ELSI) (United States of America v. Italy) [1989] ICJ Rep 15, at 42, para. 50.

2 S. Rosenne and L.B. Sohn (eds), United Nations Convention on the Law of the Sea A Commentary vol. v (Nijhoff 1989) 81. As observed by the ITLOs, 'the question whether local remedies must be exhausted is answered by international law. The Tribunal must, therefore, refer to international law in order to ascertain the requirements for the application of this rule and to determine whether or not those requirements are satisfied ...'. See $M / V$ 'SAIGA' (No 2 ) (Saint Vincent and the Grenadines v. Guinea) (Merits) IT Los Case No 2 (1 July 1999) para. 96.

3 These cases are $M / V^{\prime}$ 'SAIGA' (No 2), $M / V^{\prime}$ 'Louisa', $M / V^{\prime}$ 'Virginia $G$ ', The 'Enrica Lexie' Incident and the $M / V^{\prime}$ 'Norstar' case.

4 Arctic Sunrise Arbitration and the Duzgit Integrity Arbitration.

5 N. Klein, Dispute Settlement in the UN Convention of the Law of the Sea (OUP 2001) 101-103. Even if not required, in prompt release proceedings the prior exhaustion of local remedies is not even discouraged. See B.H. Oxman and V.P. Bantz, 'The 'Camouco' (Panama v. France) (Judgment)' (2000) 94 AJIL 713, 719. 
any other analogous rule into Art. $292^{\prime} \cdot{ }^{6}$ This is also confirmed by the drafting history of Art. 295. ${ }^{7}$ The reason for such exception lies in the very nature of the special proceedings for prompt release of vessels and crews which are aimed at obtaining expeditiously the relief and are independent of any local proceedings. ${ }^{8}$ Secondly, the local remedies rule is usually not considered by the ITLOS at the stage of provisional measures. In the Louisa case, the Tribunal held that the issue of exhaustion of local remedies should be examined 'at a future stage of the proceedings. ${ }^{9}$ In its more recent Order of 24 August 2015 in the Enrica Lex$i e$ case, the Tribunal stated that 'the issue of exhaustion of local remedies should not be addressed in the provisional measures phase. ${ }^{10}$ While there seems to be no procedural obstacle for raising exceptions under Art. 295 at the provisional measures stage, ${ }^{11}$ the Tribunal has constantly followed this approach, perhaps because provisional measures are required to be 'expeditious and procedurally urgent.12

That said, if one considers that most of the cases brought before the ITLOS are prompt release and provisional measures cases, it is evident that five cases in which the issue was addressed by the Tribunal (plus two by Annex vir Tribunals), or at least discussed by the parties, is a quite significant amount.

In neither case, however, has the exception ever been upheld by the ITLOS, nor by Annex VII Tribunals. ${ }^{13}$ Indeed, the very restrictive approach taken by

6 'Camouco' (Panama v. France) (Prompt Release) (Judgment) Itlos Case No 5 (7 February 200o) para. 57. R. Lagoni, "The Prompt Release of Vessels and Crews before the International Tribunal for the Law of the Sea: A Preparatory Report' (1996) 11 The International Journal of Marine and Coastal Law 147, 152.

7 See Rosenne and Sohn (eds), United Nations Convention on the Law of the Sea - A Commentary 81 .

8 But for a different view see the Dissenting Opinion by Judge Anderson in 'Camouco', at 1-2.

9 The $M / V$ 'Louisa' Case (Saint Vincent and the Grenadines v. Kingdom of Spain) (Provisional Measures) (Order) IT Los Case No 18 (23 December 2010) para. 68.

10 The 'Enrica Lexie' Incident (Italy v. India) (Provisional Measures) (Order) ITlos Case No 24 (24 August 2015) para. 67.

11 The question was discussed by the parties during the oral hearings. In particular, while Italy referred to the above statement in the Louisa Order considering it inappropriate to deal with the issue of local remedies at the provisional measures phase (ITLOS/PV.15/ C24/3, 9, lines 13-16), India, on the other hand, contended that the Tribunal, in so holding in the Louisa case, did not lay down a 'peremptory rule of procedural law' (ITLOS/PV.15/ C24/4, 13, lines 15-18).

12 Separate Opinion Judge Laing, 'SAIGA' (No. 2) (Provisional Measures) para. 9; See also E.A. Laing, 'A Perspective on Provisional Measures under UnCLOs' (1998) 29 NYIL 45, 52; I.V. Karaman, Dispute Resolution in the Law of the Sea (Nijhoff 2012) 115; N. Peiris, 'ARA Libertad from IT Los: How Provisional a Provisional Measure Should Be?' (2012) 25 The Hague Yearbook of International Law 159, 169.

13 The only case in which the ITLos seemingly considered the rule to be applicable is the $M / V$ 'Louisa' Case. As seen, in its order on provisional measures, the ITLos put off the 
UNCLOS Tribunals with respect to the applicability of Art. 295 has been quite controversial and a matter of frequent dissent among judges. Legal scholars have not paid much attention on this issue so far. More generally, the question of what should be the real impact of the local remedies rule in the context of dispute concerning the interpretation and application of the Convention has not been answered yet.

The difficulty in interpreting and applying the rule embodied in Art. 295 lies in the mixed character of most of the claims involving private entities (ships, persons, etc.) brought before UNCLOS Tribunals. In the Commentary to the 2006 Draft Articles on Diplomatic Protection (DADP), ${ }^{14}$ the International Law Commission (ILC or Commission) defined mixed claims as those claims containing 'elements of both injury to the State [direct injury] and injury to the nationals of the State [indirect injury]'.15 As a general rule, in case of direct injury the local remedies rule does not apply, whereas in case of indirect injury it does. When these two elements coexist, the claim is mixed. In order to determine whether the local remedies rule applies in mixed case, Art. 14 (3) DADP relies on the criterion of preponderance. The rule will be applied where a claim is brought 'preponderantly on the basis of an injury to a national', that is where the elements of indirect injury prevail over those of direct injury. ${ }^{16} \mathrm{On}$ their part, UNCLOS Tribunals have shown awareness of the ILC's works on the

examination of the local remedies exception to a future stage of the proceedings. The question, albeit discussed at length by the parties in the course of the written and oral proceedings, was finally not decided at the merits stage, since the Tribunal found it had not jurisdiction to entertain the Application due to the lack of any justiciable dispute concerning the interpretation or application of the Convention. However, even if the judgment subsequently rendered in this case does not take a stand on the issue, a hint of the Tribunal's position about the applicability of the local remedies rule in this case can be drawn from the questions the Tribunal addressed to the parties during the proceedings. On 11 October 2012, just before the closing of the oral hearings, the Tribunal asked the parties, among other questions, the following: 'Under Spanish law, what would be the further legal proceedings which would have to be pursued/instituted, if any, in the present case in order to exhaust the local remedies in accordance with international law?' (see 'List of Points That the Tribunal Would Like the Parties to Address pursuant to Article 76, Paragraph 1, of the Rules, 11 October 2012', emphasis added). From this question - to which the Applicant did not provide any answer - it can be inferred that the Tribunal finally considered the rule as applicable in case at hand. However, there is no suggestions in the judgment as to the method employed by Tribunal to reach this conclusion.

14 UN ILC 'Draft Articles on Diplomatic Protection' (2006) GAOR 61st Session Supp 10, 16.

15 Ibid., 74 (10).

16 See in general T. Meron, 'The Incidence of the Rule of Exhaustion of Local Remedies' (1959) 35 The British Yearbook of International Law 83; M.H. Adler, 'The Exhaustion of Local Remedies Rule after the International Court of Justice's Decision in ELSI' (1990) 39 ICLQ 641; S. Wittich, 'Direct Injury and the Incidence of the Local Remedy Rule' (2000) 5 Austrian Review of International and European Law 121; C.F. Amerasinghe, Local Remedies 
issue. Nevertheless, as will be shown, it does not seem that they have properly followed its suggestions.

The present article analyses the relevant case law and critically discusses the overall approach taken by UNCLOS Tribunals with respect to the applicability of the local remedies rule (Section 2). This approach is assessed against a reconsideration of the present state of international law on mixed claims (Section 3) and the specific dispute settlement regime set forth in the Law of the Sea Convention (Section 4). In the concluding section the approach followed in UNCLOS Tribunals' case law is considered in light of recent criticisms pointing out the current expansion of the jurisdiction under UNCLOS Part XV (Section 5).

Before analyzing the relevant case law, one further clarification is in order. As already mentioned, the real difficulty in assessing the applicability of the local remedies rule consists in the mixed nature of the cases in which the question arises. This article only deals with UNCLOs Tribunals' approach in determining the scope of application of the rule, that is in assessing the nature of the cases brought before them in order to establish whether or not the rule is in principle applicable. Other issues affecting the functioning of the rule, such as the exceptions to the local remedies rule ${ }^{17}$ are not addressed here. It suffices to note that UNCLOS Tribunals have not very often carried out an in-depth assessment of these issues.

The application of the local remedies rule was extensively debated for the first time in the merits phase of the $M / V$ 'SAIGA' (No 2) case. ${ }^{18}$ Guinea contended that the application of Saint Vincent and the Grenadines was inadmissible as the individuals or private entities (the Master and the owners of the SAIGA and its cargo) whose damages were claimed by the Applicant did not exhaust all local remedies available to them in Guinea. On the contrary, the Applicant argued that the rule did not apply since the violations complained of affected its own rights as a flag State under the Convention.

In its judgment of 1 July 1999, the Tribunal first considered that the rights which the Applicant claimed had been violated by Guinea were 'all rights that

in International Law (2nd ed CUP 2004) 145-168; Id., Diplomatic Protection (OUP 2008) 172-181; J. Crawford, Brownlie's Principles of Public International Law (OUP 2012) 712-713.

17 Cf. Art. 15 DADP.

18 Indeed, the Respondent State, Guinea, raised first the question at the provisional measures stage of the case. However, since the argument of local remedies was introduced for the first time only at the end of the oral proceedings, the Tribunal could not deal with the objection in its subsequent order. See ITLOS/PV.98/3, 24 February 1998, 44-46. 
belong to Saint Vincent and Grenadines under the Convention ... or under international law'.19 After referring to Art. 22 of the Draft Articles on State Responsibility adopted on first reading by the ILC, which limited the scope of the local remedies rule to violations of international obligations concerning the treatment of aliens, it then stated:

None of the violations of rights claimed by Saint Vincent and the Grenadines ... can be described as breaches of obligations concerning the treatment to be accorded to aliens. They are all direct violations of the rights of Saint Vincent and the Grenadines. Damage to the persons involved in the operation of the ship arises from those violations. Accordingly, the claims in respect of such damage are not subject to the rule that local remedies must be exhausted. ${ }^{20}$

In the passage just quoted, the Tribunal condensed for the first time its controversial approach towards the local remedies rule. This approach can be criticized for a number of reasons. ${ }^{21}$

First, by insisting on the limitation set forth in Art. 22 of the 1996 Draft Articles on State Responsibility, the Tribunal appeared to deprive Art. 295 UNCLOS of any sense. If the local remedies rule applied only with respect to international obligations concerning the treatment of aliens, Art. 295 would be meaningless as it provides for the applicability of the rule to disputes relating to UNCLOS obligations which have little or nothing to do with the treatment of aliens. ${ }^{22}$ Second, the Tribunal did not give adequate consideration to the fact that, of all the claims advanced by the Applicant, ${ }^{23}$ in the end the main question brought before it regarded the allegedly wrongful exercise of hot pursuit by Guinea authorities under Art. 111 (8) UNCLOS. As pointed out by Judges Chandrasekhara Rao and Warioba in their respective separate and Dissenting Opinions, this provision bestows rights to the ships (conceived as 'everything on the ship and every person involved or arrested in the operations of the

$19 M / V$ 'SAIGA' (No 2), Judgment, para. 97.

$20 \quad$ Ibid., para. 98

21 For a discussion see Wittich, 'Direct Injury and the Incidence of the Local Remedy Rule' 170-177; P. Chandrasekhara Rao, 'ILtos: The First Six Years' (2002) 6 Uny B 183, 274-276.

22 Cf. Wittich, 'Direct Injury and the Incidence of the Local Remedy Rule' 166-167. It should be noted that the codification evolved in this respect. See Art. 44 of the 2001 Draft Articles on State Responsibility and Art. 14 DADP. See also Ahmadou Sadio Diallo (Republic of Guinea v Democratic Republic of Congo) (Preliminary Objections) [2007] ICJ Rep 582, 599 para. 39. According to Karaman, Dispute Resolution in the Law of the Sea 304, 'the outcome in this case would have been the same even if the Tribunal had relied on the established case-law instead of Article 22 of the Draft Articles on State Responsibility'.

See $M / V$ 'SAIGA' (No 2), Judgment, para. 97. 
ship'), ${ }^{24}$ and in particular the right to be compensated for any loss or damaged caused by the wrongful stop or arrest. ${ }^{25}$ Therefore, the case appeared to be one of indirect injury to the State, as such requiring, in principle, the application of the local remedies rule. ${ }^{26}$ Thirdly, and most significantly, the approach followed by the ITLOS consisted in considering only the wording of the Applicant's submissions without making a finding on whether the alleged direct violations of the Applicant's rights were founded. To put it otherwise, the Tribunal failed to take into consideration the subject matter of the dispute as a whole. In this respect, the Tribunal's approach differed from that of the ICJ, which, in both Interhandel and ELSI cases, ascertained that 'the matter which colour[ed] and pervade[ed] ... the claim as a whole' was the alleged damage to the persons involved, 'said to have resulted from the actions of the Respondent'. ${ }^{27}$

In his Separate Opinion, the then Vice-President Wolfrum put the issue in the following terms. He first recalled the dictum of the ICJ, whereby

claims to be exempt from the scope of the local remedies rule have to be 'both distinct from, and independent of' the dispute of the alleged violation in respect of the individual involved. ${ }^{28}$

He then observed that

to decide whether this is the case does not depend upon the wording of the claims made, it is rather necessary to determine the nature of the injury and the rights involved. ${ }^{29}$

Accordingly, although some of the submissions were phrased in terms of violations of rights of the Saint Vincent and the Grenadines, it could 'hardly be denied that the dispute would not have occurred without the arrest of the

24 Separate Opinion Judge Chandrasekhara Rao, para. 15.

25 Ibid., paras 14-15; Dissenting Opinion Judge Warioba, para. 61.

26 Both judges however agreed with the finding of the Tribunal (Judgment, para. 100) that in the present case the rule that local remedies must be exhausted did not apply due to the absence of a jurisdictional connection between the person suffering damage and the State responsible for such damage.

27 Interhandel (Switzerland v. United States of America) (Preliminary Objections) [1959] ICJ Rep 6, 28-29; and ELSI 43, para. 52.

28 Separate Opinion Judge Wolfrum, para. 48 (quoting ELSI 42-43, para. 51).

29 Ibid., para. 48 (emphasis added). 
Saiga by the authorities of Guinea' ${ }^{30}$ Moreover, it was 'beyond question that the arrest of Saiga had negative implications predominantly for the owner of the ship, its charterer and its crew'. ${ }^{31}$ Now, while these latter considerations are close to the views expressed by Judges Chandrasekhara Rao and Warioba - all essentially based on the predominance of the indirect injury -, Judge Wolfrum went even further arguing that the freedom of navigation - which encompasses also the freedom not to be subject to illegal hot pursuit - has in general 'as its addressees States as well individuals or private entities'. ${ }^{32}$ Setting here aside for a moment the controversial issue whether the freedom of navigation is a right of States only or also a right of ships ${ }^{33}$ this means that it is inevitable that a violation of that freedom causes injury to the affected ship too. And this is so regardless the wording of the provisions invoked, which might not necessarily refer to individuals or private entities. Therefore, according to Judge Wolfrum,

to the extent the subject matter of a dispute concerns an alleged violation of the freedom of navigation, it is impossible to find a dispute over alleged violations of the Convention which is both distinct from, and independent of, a dispute over the alleged violation of the rights of the ship involved. ${ }^{34}$

Even more than the 'SAIGA' (No 2), the $M / V^{\prime}$ Virginia $G$ ' case testifies the controversial nature of the issue concerning the scope of the local remedies rule in UNCLOS disputes. Indeed, the local remedies objection was a matter of significant divide among judges, as it was rejected by fourteen votes to nine. ${ }^{35}$

$30 \quad$ Ibid., para. 49 .

31 Ibid., para. 49 (emphasis added). According to Judge Wolfrum this was reflected by the judgment since ' $[\mathrm{i}] \mathrm{t}$ awards compensation mainly to members of the crew, the captain, the owner and the charterer of the vessel ..., however, no compensation to Saint Vincent and the Grenadines directly'.

32 Ibid., para 51.

33 On this issue, it seems that Judge Wolfrum upheld the view that the freedom of navigation is a right of ships too. At para. 53 of his Separate Opinion, he held in particular that ' $[\mathrm{t}] \mathrm{he}$ provisions of the Convention indicate that concerning freedom of navigation the rights of States and those of individuals are interwoven. It is significant that - in respect of the freedom of fishing - article 116 of the Convention refers to the right of States for their nationals to engage in fishing. A similar wording would have appropriately qualified the freedom of navigation'. For further discussion, see Section 4.

34 Separate Opinion Judge Wolfrum, para. 54.

$35 M / V$ 'Virginia G' (Panama v Guinea Bissau) (Judgment) ITLos Case No 19 (14 April 2014) para. 57. For a comment see R. Churchill, 'Dispute Settlement in the Law of the Sea: Survey for 2014', (2015) 30 The International Journal of Marine and Coastal Law 585, 595 . 
In addressing the local remedies rule, the Tribunal first considered the nature of the claims made by Panama, namely whether the claims of Panama (the Applicant) related to a direct violation on the part of Guinea-Bissau (the Respondent) of the rights of Panama. ${ }^{36}$ Then, referring approvingly to the approach followed in 'SAIGA' (No 2), ${ }^{37}$ the Tribunal looked at the rights allegedly violated by Guinea-Bissau as set out in the final submissions of Panama and noted that

most provisions of the Convention referred to in the final submissions of Panama confer rights mainly on States. ... [I]n some of the provisions referred to by Panama, however, rights appear to be conferred on a ship or persons involved. ${ }^{38}$

As to the criterion to use in case of mixed disputes, the Tribunal observed:

When the claim contains elements of both injury to a State and injury to an individual, for the purpose of deciding the applicability of the exhaustion of local remedies rule, the Tribunal has to determine which element is preponderant. In the present case, the Tribunal is of the view that the principal rights that Panama alleges have been violated by Guinea-Bissau include the right of Panama to enjoy freedom of navigation and other internationally lawful uses of the seas in the exclusive economic zone of the coastal State and its right that the laws and regulations of the coastal State are enforced in conformity with article 73 of the Convention. Those rights are rights that belong to Panama under the Convention, and the alleged violations of them thus amount to direct injury to Panama. Given the nature of the principal rights that Panama alleges have been violated by the wrongful acts of Guinea-Bissau, the Tribunal finds that the claim of Panama as a whole is brought on the basis of an injury to itself. ${ }^{39}$

As can be inferred from the passages just quoted, the Tribunal reasoned on the basis of the test of preponderance as adopted by the ILC in Art. 14 (3) DADP,

$36 \quad M / V^{\prime}$ 'Virginia $G^{\prime}$, Judgment, paras $15^{2-154}$.

37 Ibid., para. 155 .

38 Ibid., para. 156 (emphasis added).

39 Ibid., para. 157 (emphasis added). The Tribunal went on in considering that 'the claim for damage to the persons and entities with an interest in the ship or its cargo arises from the alleged violations referred to in the preceding paragraph. Accordingly, the Tribunal concludes that the claims in respect of such damage are not subject to the rule of exhaustion of local remedies' (para. 158). 
albeit it did not expressly refer to the ILC's work. The Tribunal appeared to conceive the test of preponderance as allowing it to consider only the prevalence, in quantitative terms, of the Applicant's claims (as set out in its final submissions) based on provisions of the Convention conferring rights on States. However, as we shall see, the preponderance method does not really rely on the type of provisions invoked by the Applicant, but on different factors, such as the subject of the dispute, the nature of the claim and the relief sought. These factors have not been considered by the Tribunal when deciding on the applicability of the local remedies rule. In this respect, the judgment not only confirmed the approach adopted in 'SAIGA' (No 2), which was merely based upon the wording of the claims made, but also apparently misconceived the ILC's indications as to the test of preponderance.

It is then not surprising that the approach put forward again in the 'Virginia $G^{\prime}$ judgment met with dissent by a considerable minority. ${ }^{40}$ According to Judge Jesus the Tribunal wrongly brought into play the argument of preponderance of rights, to justify altering Panama's own characterization of the subject matter of the case. ${ }^{41}$ Indeed, Panama itself, in its Memorial, first characterized the case as a case of diplomatic protection, ${ }^{42}$ despite later insisting on the fact that it was bringing the claims 'based upon its rights as a flag State, as granted to it, as a State' under the Convention. ${ }^{43}$ More generally, the critics to the Tribunal's reasoning stressed on the mischaracterization of the preponderance test referred to in the judgment which was simply used to confirm and support the 'SAIGA' (No 2) approach. As observed by Judges Cot and Kelly in their joint Separate Opinion - and as we shall see in more detail in the next Section - this latter approach 'does not reflect the present state of international law on the subject'.44 According to them,

[i]t is not enough to say that Guinea-Bissau has violated the direct rights of the flag State and that there is no obligation to exhaust local remedies

40 Joint Dissenting Opinion of Vice-President Hoffmann and Judges Marotta Rangel, Chandrasekhara Rao, Kateka, Gao and Bouguetaia, paras 3-10; Dissenting Opinion of Judge Jesus, paras 64-80; Dissenting Opinion of Judge Ndiaye, paras 123-160; and Dissenting Opinion of Judge ad hoc Sérvulo Correia, paras 8-10. Criticisms to this approach came also from judges who voted in favour of the rejection of the local remedies objection. See Joint Separate Opinion Judges Cot and Kelly, paras 1-20.

41 Dissenting Opinion of Judge Jesus, para. 78; See also Dissenting Opinion of Judge Ndiaye, paras $123^{-127}$.

42 Memorial of the Republic of Panama, 23 January 2012, paras 15-17.

43 Reply of the Republic of Panama to Guinea-Bissau's Counter-memorial and Counterclaim, 28 August 2012, para. 164. See also the Judgment, paras 142-143. Joint Separate Opinion Judges Cot and Kelly, para. 5 . 
simply because there has been a direct injury to these rights. The Tribunal must assess the overall situation and legally qualify the dispute brought before it. ${ }^{45}$

In the Arctic Sunrise Arbitration, the Netherlands claimed that the provisions invoked directly conferred rights upon the flag State and 'failure to comply with the ensuing obligation to respect these rights causes direct injury to the flag State. ${ }^{46}$ Therefore, the local remedies rule was deemed to be inapplicable. In its award on the merits, the Annex vir Tribunal upheld the applicant's position and aligned itself with the previous ITLOS case law on the matter. ${ }^{47}$ With respect to the UNCLOS provisions at stake, it held that they 'set out some of the rights conferred upon and obligations owed to States under the Convention.48 More directly, and without further reasoning, it concluded that the requirement for exhaustion of local remedies was 'inapposite' since 'the claims are direct claims brought by the Netherlands against Russia under the Convention.49

As already mentioned, the question of the scope of the local remedies rule arose also in the Enrica Lexie case, although in its Order of 24 August 2015, the IT LOS dealt quite hastily with the issue, which did not subsequently arise before the Annex VII Tribunal. It will be reminded that the Tribunal decided not to address the local remedies issue in the provisional measures phase 'since the very nature of the dispute concerns the exercise of jurisdiction over the Enrica Lexie incident'. 50 This latter passage is rather ambiguous. ${ }^{51}$ The causal nexus between 'the very nature of the dispute' and the need to not address the issue of local remedies at the provisional measures stage is hard to see. It is likely that the Tribunal only wished to recall the parties, and perhaps the competent arbitral Tribunal, that, despite the kind of provisional measures requested, the subject matter of the dispute did not directly pertain to the protection of the two marines, but to the determination of the State entitled to exercise the jurisdiction over the incident. Therefore, the question of local remedies would

$45 \quad$ Ibid., para. 13 .

46 Memorial of the Kingdom of the Netherlands, para. 96 (referring to Art. $5^{8}$ UnCLOs). See also paras 97 and 98 with respect to Arts 92, 290 (6) and 296 (1) UNCLOS.

47 Arctic Sunrise Arbitration (The Netherlands v. Russian Federation) (Merits) Annex viI Tribunal (14 August 2015) http://www.pca-cpa.org (13 June 2017). See J. Harrison, 'Current Legal Developments. The Arctic Sunrise Arbitration (Netherlands v. Russia)' (2016) 31 The International Journal of Marine and Coastal Law 145, 148.

48 Arctic Sunrise Arbitration, Award, para. 168.

49 Ibid. para 173 .

50 The 'Enrica Lexie' Incident, Order, para. 67.

51 A. Cannone, 'L'ordinanza del Tribunale internazionale del diritto del mare sulla vicenda della Enrica Lexie', (2015) 98 Riv. Dir. Int. 1144, 1150. 
have been better addressed in a different phase specifically devoted to the very subject matter of the dispute. Be that as it may, by leaving open the question of local remedies, the Tribunal not only followed the same line of the 'Louisa' case. It also implicitly suggested that the local remedies objection should be dealt with by the Annex vir Tribunal in light of the 'very nature of the dispute' as identified by it.

In the Award of 5 September 2016 handed down in the matter of the Duzgit Integrity Arbitration an Annex VII Tribunal took up the question of the applicability of Art. 295 UNCLOS once more. Interestingly, the Award stands out against other decisions already examined. The arbitral Tribunal expressly relied on the ILC'S DADP and on the Virginia G judgment. However, while recognizing the difficulty in determining whether the mixed claim was preponderantly direct or indirect, the task of the Tribunal was simplified by one specific circumstance. The main private entity (DS Tankers) which suffered injury that could 'be seen as giving rise to an 'indirect' claim of Malta [could not] avail itself of any remedy in São Tomé, since such entity had already concluded an agreement with the Respondent in which it gave up and waived all local remedies available to it. ${ }^{52}$ Accordingly, the Tribunal held that

the direct claims of Malta for injury suffered as a State may be considered as preponderant. Consequently, there is no need that the private entities involved different from DS Tankers exhaust local remedies. ${ }^{53}$

While the Tribunal did not have the chance to elaborate in detail on the preponderance test, it is important to stress that the judgment at hand decisively departed from the 'SAIGA' (No. 2) and the 'Virginia G' approach, which, as seen, ultimately took into account only the wordings of the claims made by the applicants and the fact that rights allegedly violated belonged to them under the Convention, as such automatically entailing only direct injury to them.

The recent judgment rendered by the ITLOS in the $M / V$ 'Norstar' case signals a further confirmation of the 'SAIGA' (No 2) and 'Virginia $G$ ' approach. In this case, the Tribunal stated that it would follow the same approach as in the 'SAIGA' (No 2) and 'Virginia G' cases by examining the 'nature of the rights' invoked by the Applicant. ${ }^{54}$ It then recalled that, among the provisions

52 The Duzgit Integrity Arbitration (Malta v. São Tomé and Príncipe) Annex viI Tribunal (5 September 2016) http://www.pca-cpa.org (13 June 2017) paras 154-155.

53 Ibid., para. 156.

54 The $M / V$ 'Norstar' Case (Panama v. Italy) (Preliminary Objections) Ituos Case No 25 (4 November 2016) paras 267-268. 
invoked by the Applicant, Articles 87 and 300 UNCLOS were considered relevant to the present case in order to determine the existence of an UNCLOS dispute. Without even mentioning the test of preponderance - which was indeed applied, albeit superficially, in the Virginia G judgment -, the Tribunal concluded that

the right of Panama to enjoy freedom of navigation on the high seas is a right that belongs to Panama under article 87 of the Convention, and that a violation of that right would amount to direct injury to Panama. ${ }^{55}$

The conclusion reached in the judgment met with several opinions by judges, either upholding and criticizing the Tribunal's approach. On the one hand, while stating that the issue merited further reasoning by the Tribunal, Judge Heidar finally confirmed this approach. The Tribunal's approach was also endorsed by Judges Wolfrum and Attard, who in their joint Separate Opinion concluded that although it renders the application of Art. 295 'moot in mixed cases ... it is to be hoped that this case finally stabilizes the jurisprudence of the Tribunal. ${ }^{56}$ On the other hand, Judge $a d$ hoc Treves (who also sat as arbitrator in the Duzgit Integrity Arbitration) and Judge Cot strongly criticized the Tribunal's approach. In Judge Treves's opinion,

[f]ollowing this approach mixed cases to which the preponderance test may apply would never exist. The practical effect would be to eliminate or drastically reduce the relevance of article $295 \cdot{ }^{57}$

In a similar vein, Judge Cot observed that

[b]y excessive reliance on the concept of direct injury to the flag State, the Tribunal is ignoring the clear wording of article 295 of the Convention, rendering it devoid of any meaning. ${ }^{58}$

55 Ibid., para. 270. Like in the $M / V^{\prime}$ Virginia $G$ ', the Tribunal then added that 'the claim for damage to the persons and entities with an interest in the ship or its cargo arises from the alleged injury to Panama. Accordingly, ... the claims in respect of such damage are not subject to the rule of exhaustion of local remedies' (para. 271).

56 Separate Opinion of Judges Wolfrum and Attard, para. 50.

57 Dissenting Opinion of Judge ad hoc Treves, para. 20.

$5^{8}$ Declaration of Judge Cot, para. 5. He went on observing that '[i]t is difficult to imagine a situation in which the Tribunal, in a given case, would not invoke direct injury to the claimant State'. 
With the sole exception of the Duzgit Integrity award, the practice of UNCLOS Tribunals surveyed above is indicative of a rather restrictive approach towards the applicability of the local remedies rule and, consequently, of Art. 295 UNCLOS. In neither case where private entities/persons were involved in an UNCLOS dispute these tribunals considered the local remedies rule to be applicable due to the direct nature of the injury caused to the flag State. This practice is essentially based on the idea that an alleged violation of an UNCLOS provision entails, in and of itself, a direct injury to the flag State. Hence, specific claims for damages to private persons simply arise from the alleged direct injury and do not have to be subject to the local remedies rule.

This approach is not fully persuasive since, absent proper legal reasoning, it fails to align with - or expressly depart from - what appears to be the present state of international law on the issue, as also resulting from the indications by the ILC on the topic.

As seen, under Art. 14 (3) DADP, the scope of application of the local remedies rule depends on the direct/indirect character of the international claim brought by a State. While this distinction might appear easy to grasp in principle, in practice it is difficult to qualify a claim as direct or indirect where it is mixed, 'in the sense that it contains elements of both injury to the State and injury to the nationals of the State'.59 Mixed claims are likely to arise when private entities, such as private ships, are affected by the allegedly wrongful conduct underlying the international dispute. The claimant State in this case is acting not only to seek redress for an injury caused directly to it by another State resulting from an international wrongful act, but also to espouse the individual claims of its nationals when they have been injured by the same international wrongful act.

The ILC attempted to resolve the conundrum of mixed claims through the criterion of preponderance: the local remedies rule applies where the international claim is brought preponderantly on the basis of an injury to a national. In the Commentary to Art. 14, the Commission further specified that the determination of the preponderance of the direct or the indirect elements of a claim is not to be left to the claimant State, but should be objectively assessed by the international tribunal seised of the case by weighing up all relevant elements of the claim. ${ }^{60}$

59 Ibid., at para. 10

6o UN ILC 'Draft Articles on Diplomatic Protection' (2006) GAOR 61st Session Supp 10, 75 (11): 'In the case of a mixed claim it is incumbent upon the tribunal to examine the 
According to the ILC, the principal factors to be assessed within the preponderance test are the subject of the dispute, the nature of the claim and the remedy claimed. As to the subject of the dispute, there are cases where the mixed character of the claim does not prove particularly problematic for the determination of the applicability of the local remedies rule due to the specific subject of the dispute. International practice shows that where a dispute involves, for example, Government or diplomatic officials or State property, the claim will be normally direct, even if the internationally wrongful act has simultaneously caused injury to claimant State's nationals. ${ }^{61}$ The second factor indicated by the ILC, that of the nature of the claim, is drawn from Meron, who elaborated for the first time on the relevance the nature of the claim, to be found in the 'real interests and objects pursued by the claimant State'.62 As to the remedy claimed, the ILC considered that the demand for monetary relief on behalf of the claimant State's national as a private individual is suggestive of the indirect character of the claim. ${ }^{63}$ Yet, a request for a decision on the interpretation and application of a treaty (declaratory judgment) allegedly violated is not necessarily indicative of a direct injury. ${ }^{64}$

Besides the preponderance test, the ILC also mentioned the sine qua non test or 'but for' test which asks whether the mixed claim would have been brought 'were it not for the claim on behalf the injured national'. ${ }^{5}$ In other words, such test consists in questioning whether a State would have brought a claim even if the national had not suffered injury. If the answer is in the positive, the claim will be qualified as direct. Conversely, if the answer is in the negative, the claim will be indirect and the local remedies rule applies. Admittedly, as underlined by the ILC, the preponderance and the 'but for' tests are essentially analogous. ${ }^{66}$

different elements of the claim and to decide whether the direct or the indirect element is preponderant'.

61 Ibid., $75^{-76}$ (12).

62 Meron, 'The Incidence of the Rule of Exhaustion of Local Remedies' 87. Such a factor found some support in the Interhandel case, where the ICJ considered that 'one interest, and one alone, that of Interhandel, which has led the latter to institute and to resume proceedings before the United States courts, has induced the Swiss Government to institute international proceedings' (Interhandel 29). In a similar vein, H. Thirlway, 'The Law and Procedure of the International Court of Justice, 1960-1989' (1995) 66 British Yearbook of International Law 89 .

63 GAOR 61st Session Supp 10, 76 (12).

64 Ibid., 76 (13).

65 This test is drawn from Adler, 'The Exhaustion of Local Remedies Rule after the International Court of Justice's Decision in ELSI' 651-652, who relied upon the ELSI case.

66 GAOR 61st Session Supp 10, 75 (11): 'If a claim is preponderantly based on injury to a national this is evidence of the fact that the claim would not have been brought but for the injury to the national'. 
It goes without saying that the test of preponderance suggested by the Commission, together with those factors to be considered in order to qualify the claim as direct or indirect, does not provide a decisive method for ascertaining unequivocally whether a claim should be considered as a direct or an indirect one. As the Commission itself admitted, "[i]n practice it is difficult to decide whether the claim is "direct" or "indirect" where it is "mixed".67 The criterion of preponderance simply provides some guidance for the international judge to ease this difficult task which can vary from case to case.

The approach set out by the ILC has not been met with widespread acceptance in legal literature. Among the critics of the ILC's approach towards the issue of mixed claims are those authors who insist on the nature or essence of the rights allegedly violated, rather than on the nature of the injury. ${ }^{68}$ For instance, Wittich highlights the circularity of the arguments based on the preponderance or the 'but for' tests:

$[T]$ he answer to the question when the element of direct injury prevails over that of indirect injury presupposes the prior determination of what distinguishes one from the other. ${ }^{69}$

This goes in particular for the three factors to be assessed through the preponderance method. Apart from those cases well established in practice (involving State property and Government or public officials), the subject of the dispute cannot be taken as a decisive factor for all possible cases. It does not provide a general criterion which helps distinguishing direct claims from claims of diplomatic protection, but simply takes account of what have been decided in practice. The remedy sought is still not determinant, first, because of the frequent practice of States seeking 'mixed' remedies in international claims; ${ }^{70}$ secondly, it has been shown that such factor has not always been accorded a decisive weight in case law. ${ }^{71}$ The nature of the claim, finally, is a quite ambiguous factor. Rather than being elements for determining the direct/indirect nature of the claim, the 'real interests and objects pursued by the claimant State' can be discerned only once it has been ascertained that the claim is one of diplomatic protection or direct injury. In this sense, the determination of the

$67 \quad$ Ibid., 74 (10).

68 Amerasinghe, Diplomatic Protection 179-181, and Wittich, 'Direct Injury and the Incidence of the Local Remedy Rule' 181-187.

69 Wittich, 'Direct Injury and the Incidence of the Local Remedy Rule' 136.

70 See for discussion UN ILC Special Rapporteur J Dugard 'Second Report on Diplomatic Protection' (28 February 2001) UN Doc A/CN.4/514, 14, paras 28-30.

71 Wittich, 'Direct Injury and the Incidence of the Local Remedy Rule' 170 and 182. 
factor that should help in assessing the direct/indirect nature of claim would depend, in turn, on the nature of the claim itself. ${ }^{72}$

According to the critics of the ILC approach, what really counts, ultimately, is the nature or the essence of the right(s) allegedly violated. In order to establish whether a claim pertains to a case of diplomatic protection or a case of direct injury it is essential to enquire about the primary norm, since any claim, 'whatever it may be and whatever relief is sought by it, depends on the substantive right on which it is based. ${ }^{73}$ Therefore, one should look first at the primary norm allegedly violated and determine

whether the right invoked has for its specific or primary object the protection of the private individuals involved as the ultimate beneficiary of this right, even if the formal holder of the relevant right is the State. ${ }^{74}$

Admittedly, the 'nature of the right(s) approach' has some merits especially in that it is grounded on the distinction between the formal right-holders and right-beneficiaries of a certain norm which may not necessarily coincide. It is not enough, for instance, to state that since Art. 87 UNCLOs formally accords the freedom of navigation to States any violation of that right would for this reason amount to a direct injury to the State. Following this approach, however, one could not rely simply on the interpretation of a certain norm in order to determine who are the actual beneficiries of the right provided by that norm. Regard must always be given to the specific context and circumstances of the case. Indeed, context and circumstances might either show that the State, being the formal right-holder, was also as the primary right-beneficiary in that specific case - and consequently had been directly injured by the breach of the relevant norm -, or that the actual beneficiary of that State's right was - in that specific case - primarily the individual or the private entity affected directly by the wrongful conduct, thus giving rise to an indirect claim by the State. That said, it should be observed that the context and circumstances to be considered in order to assess the possible discrepancy between the right-holder and the right-beneficiaries in a specific case include, in fact, those factors underpinning the preponderance test, namely the subject of the dispute, the nature of the claim and the remedy sought.

$72 \quad$ Ibid., 135 .

73 Ibid., 137. As Amerasinghe, Diplomatic Protection 181 put it, 'it is really the nature of the 'right' violated as being preponderantly one relating to an alien or his property that needs to be considered in determining the indirectness of the injury'.

Wittich, 'Direct Injury and the Incidence of the Local Remedy Rule' 182. 
It can therefore reasonably be assumed that the two approaches of the 'nature of the right' and the 'preponderance' are not mutually exclusive, but can be combined and reconciled. The determination of the direct or indirect nature of the claim should accordingly start first from an inquiry into the right allegedly violated. The analysis should then move to the context and circumstances of the case, which means taking into account the factors of the preponderance test.

Together with the nature of the rights allegedly violated and the factors of the test of preponderance, an even more comprehensive enquire into the dispute dividing the parties would also help in determining the nature (direct/ indirect) of the claim. As observed by Judges Cot and Kelly, in carrying out this task the international judge 'must assess the overall situation and legally qualify the dispute brought before it. ${ }^{75}$ In this respect, that complex operation consisting in the characterization of the dispute may serve not only to identify the object of the claim, but also to provide some further help in the determination of the nature of the claim. As an Annex VII Tribunal summarized this operation in the award rendered in the Chagos case,

it is for the Tribunal itself 'while giving particular attention to the formulation of the dispute chosen by the Applicant, to determine on an objective basis the dispute dividing the parties, by examining the position of both parties' ... and in the process 'to isolate the real issue in the case and to identify the object of the claim. ${ }^{76}$

This task requires the international tribunal to consider also the 'context of the submission' and 'the manner in which it has been presented', namely all other factors that may help in objectively establish the dispute 'actually separating the Parties.' ${ }^{77}$ An assessment of the context of the submission could shed light on a series of circumstances that might help the tribunal to deem the international claim preponderantly direct or indirect in nature. For instance, where a claim refers to a dispute having deep historical roots between

$75 M / V^{\prime}$ Virginia $G$ ', Joint Separate Opinion Judges Cot and Kelly, para. 13.

76 Chagos Marine Protected Area Arbitration (Mauritius v. United Kingdom) Annex viI Tribunal (18 March 2015) http://www.pca-cpa.org (13 June 2017) para. 208, quoting Fisheries Jurisdiction (Spain v. Canada), Jurisdiction of the Court, Judgment of 4 December 1998, [1998] ICJ Rep. 432, at 448, para. 30, and Nuclear Tests (New Zealand v. France), Judgment of 20 December 1974, [1974] ICJ Rep. 457, at 466, para. 30.

77 Chagos Marine Protected Area Arbitration para. 229. See S. Talmon, 'The Chagos Marine Protected Area Arbitration: Expansion of the Jurisdiction of UnCLOS Part XV Courts and Tribunals' (2016) 65 ICLQ 927, 933-934. 
two States or having triggered a large amount of high-level diplomatic correspondence between the parties, this might suggest the direct, or predominantly direct, nature of that specific claim. Conversely, where the context reveals a scarce involvement of the claimant government since the origins of the dispute, and a subsequent intervention only after part of local remedies have been exhausted, this might display the espousal or indirect character of the international claim. ${ }^{78}$

True, the process of characterizing a dispute remains an 'inherently subjective exercise'. ${ }^{79}$ Likewise, the process of determining the nature of the claim for the purpose of establishing the applicability of the local remedies rule requires always an operation of weighing and balancing the different factors that the tribunal considers of relevance on a case-by-case basis. But it is one thing for an international tribunal to enjoy a certain margin of discretion in establishing the nature of a claim and another thing to exercise such discretionary power absent careful legal reasoning, as seems to have been done by UNCLOS Tribunals thus far.

\section{Mixed Claims and the Law of the Sea: A Special Regime?}

The above observations on mixed claims can also be applied to the freedom of navigation and related rights which are usually at stake when private entities are involved in UNCLOS disputes. While in some UNCLOS provisions (such as Art. $111(8))^{80}$ private entities are expressly regarded as the effective

78 In this respect, Judge Cot, in his Declaration appended to the ITLos judgment in the $M / V$ 'Norstar' Case, stressed the very little participation of Panama's authorities during the proceedings before the Tribunal. In his language, '[p]reponderance of direct injury to Panama in the present case is all the more noticeable when considering the very discreet presence of the Panamanian authorities throughout the proceedings. ... The written and oral proceedings were led by Mr Carreyó, member of the bar of Panama and representative of the Norwegian owner of the Norstar, Mr Mörch. Nothing prevents a State from appointing a private person as agent in a litigation brought before an international tribunal. However, I cannot help but notice that Panama did not find it necessary to ask one of its officials to plead during the hearing. The only official of Panama was the very silent Ship Registration Officer of the Consulate General of Panama in Hamburg. To say the least, it was quite an unusual situation for litigation before a public international law court or tribunal' (paras 6-7).

79 Talmon, "The Chagos Marine Protected Area Arbitration: Expansion of the Jurisdiction of UNCLOS Part XV Courts and Tribunals' 934.

8o This provision reads as follows: 'Where a ship has been stopped or arrested outside the territorial sea in circumstances which do not justify the exercise of the right of hot pursuit, it shall be compensated for any loss or damage that may have been thereby sustained'. 
beneficiaries of the norm, if not the formal holders of the right therein provided, the freedom of navigation remains a right conceived as having an interstate character which is placed in a 'State-centred regime', such as the law of the sea. ${ }^{81}$ As recently observed by the current Registrar of the ITLOS, Philippe Gautier, it is possible to consider that also a provision like Art. 111 (8) UNCLOS has

an inter-State character on the ground that it constitutes an exception to the right of navigation on the high seas, a right clearly granted to the flag State under Article go of the Convention, and to the right of that State to exercise its exclusive jurisdiction on the high seas over ships flying its flag, as provided in Article 92 of the Convention. ${ }^{82}$

This notwithstanding, one cannot but share the view that, since navigation at sea is today mostly undertaken by private entities, these latter are ' $[\mathrm{t}]$ he main direct beneficiaries of the freedom of navigation' ${ }^{83}$ That is not to say that private entities (ships, vessels) are formal holders of freedom of navigation together with their flag States, but simply that they are also allocated the benefits of this right, and that de facto they almost always primarily enjoy such benefits.

Under this perspective, while Vice-President Wolfrum's suggestion in 'SAIGA' (No 2) that the freedom of navigation is also a right of ships seems to rest on an 'extremely progressive interpretation of the freedom of navigation', 84 the method employed by him appears nonetheless quite sound. As seen, he pointed out that the determination of the nature of the claim does not depend upon the wording of the claim made. He then combined an assessment of the nature of the right at stake (the freedom of navigation) - stressing the nature 'necessarily' mixed of disputes involving private ships - with considerations relating to the circumstances of the arrest of the SAIGA, which had 'negative implications predominantly for the owner of the ship, its charterer and its crew'. ${ }^{85}$

81 I. Papanicolopulu, 'Human Rights and the Law of the Sea' in D. Attard, M. Fitzmaurice and N.A. Martínez Gutiérrez (eds), The IMLI Manual on International Maritime Law: Volume I: The Law of the Sea (Ou 2014) 510.

82 P. Gautier, 'On the Classification of Obligations in International Law', in H.P. Hestermeyer et al. (eds), Coexistence, Cooperation and Solidarity: Liber Amicorum Rüdiger Wolfrum vol. I (Brill 2012) 869, note 63.

83 P. Wendel, State Responsibility for Interferences with the Freedom of Navigation in Public International Law (Springer 2007) 86: 'Only indirectly, their States of origin and the States importing or exporting goods carried by maritime transport benefit from the freedom of navigation'.

84 Ibid., at 84 .

85 Separate Opinion of Vice-President Wolfrum, para. 49. 
It should then appear clear from the above considerations relating to mixed claims in international law that the approach towards the local remedies rule followed by UNCLOS Tribunals does not find clear support in international practice and falls short of adequate motivation. If everything ultimately depends on the wording of the applicant's submissions and on the right-holder as formally identified by the invoked provision, it is apparent that UNCLOS Tribunals would never find applicable the local remedies rule. Indeed, by employing these criteria, it would be relatively painless for applicants to circumvent the local remedies rule even where the claim is basically espousal in nature. More generally, this approach fails to recognize the necessarily mixed nature of disputes involving private ships and hinders the local remedies rule from functioning properly.

Having said this, one might be tempted to justify such approach by considering the local remedies rule as generally not applicable to UNCLOS disputes involving private entities due to the 'special regime' in which these disputes are supposedly enclosed. An argument of this kind was adopted by the ICJ in the Avena and Other Mexican Nationals case, where none of the suggestions coming from the then ongoing work of the ILC was even considered by the Court when assessing the character of Mexico's claims. ${ }^{86}$ In that case, the Court simply relied on the 'special circumstances of interdependence of the rights of the State and of individual rights' in the regime established by the Vienna Convention on Consular Relations (VCCR). Accordingly, Mexico could request the Court to rule on the violation of rights which it claimed to have suffered 'both directly and through the violation of individual rights conferred on Mexican nationals under Art. 36, paragraph $1(b)$ [VCcR]'. In the Court's view, Mexico's claim of diplomatic protection was absorbed by its direct claim because of that special interdependence between State and individual rights in the VCCR. ${ }^{87}$ Consequently, the duty to exhaust local remedies did not apply to such request. ${ }^{88}$

According to one author, in Avena the Court 'tried to establish a special legal regime that would constitute an exception to the standard practice. ${ }^{89}$ Shifting

86 Avena and Other Mexican Nationals (Mexico v. United States of America) [2004] ICJ Rep. 12. See the Separate Opinion of Judge Vereshchetin, Ibid., at 79, and the Separate Opinion of Judge Parra-Aranguren, Ibid., 88. Among commentators see the critical observations by A. Künzli, 'Case Concerning Mexican Nationals' (2005) 18 LJIL 49, and by E. Milano, 'Diplomatic Protection and Human Rights before the I.C.J.' (2004) 35 NYIL 85.

87 See A. Pellet, 'La seconde mort d'Euripide Mavrommatis? Notes sur le projet de la C.D.I. sur la protection diplomatique', in N. Angelet et al (eds), Droit du pouvoir, pouvoir du droit - Mélanges offerts à Jean Salmon (Bruylant 2007) 1359, 1374.

88 Avena and Other Mexican Nationals, para. 40.

89 Künzli, 'Case Concerning Mexican Nationals' 53. 
the focus to the UNCLOS dispute settlement regime, it seems however that a similar 'special legal regime' would be hardly justified. Suffice it to recall here that Art. 295 UNCLOS expressly provides for the local remedies rule by making a renvoi to the customary international law on the subject. Tacit or implied abrogation of Art. 295 would not be tenable since, as confirmed by the ICJ in the ELSI judgment, one cannot accept that

an important principle of customary international law should be held to have been tacitly dispensed with, in the absence of any words making clear an intention to do so. ${ }^{90}$

Indeed, the travaux préparatoires of Art. 295 confirm that, after several discussions on the subject, it was understood that the customary rules relating to the exhaustion of local remedies rule would apply also to law of the sea disputes. ${ }^{91}$ Accordingly, it can be reasonably argued that U NCLOS Tribunals' approach towards Art. 295 - insofar as it precludes de facto the applicability of the local remedies rule embodied therein - is in contrast with an established principle of treaty interpretation, that of the 'effectiveness', which, as known, aims at avoiding that a treaty provision is interpreted in such a way that would render it 'devoid of purport and effect'. 92

Once excluded the possibility of a 'special legal regime', there may still be some temptation to infer the existence of one 'special exception' to the local remedies rule from the so-called 'ship-as-a-unit' doctrine, as codified by the same ILC in Art. 18 DADP. ${ }^{93}$ UNCLOS Tribunals frequently resort to this doctrine. The Arctic Sunrise case provides an interesting example in this regard. In this case, besides claiming its standing to invoke Russia's responsibility for breaches of the obligations owed to it as a flag State, the Netherlands also claimed to have standing to invoke Russia's responsibility for injury caused to all persons on board the ship flying its flag for the breach of individual rights.

\footnotetext{
$90 \quad$ ELSI, para 50.

91 Rosenne and Sohn, United Nations Convention on the Law of the Sea - A Commentary $79^{-81 .}$

92 Corfu Channel Case (United Kingdom of Great Britain and Northern Ireland v. Albania) (Merits) [1949] ICJ Rep 4, 24.

93 'The right of the State of nationality of the members of the crew of a ship to exercise diplomatic protection is not affected by the right of the State of nationality of a ship to seek redress on behalf of such crew members, irrespective of their nationality, when they have been injured in connection with an injury to the vessel resulting from an internationally wrongful act'.
} 
According to it, 'these rights are to be considered as part of the direct claim, not subject to the exhaustion of local remedies' ${ }^{94}$ In this respect, the arbitral Tribunal resorted to the ship-as-a-unit concept - as the ITLOS did in its previous order on provisional measures $-{ }^{95}$ and found that the Netherlands was entitled to

bring claims in respect of alleged violations of its rights under the Convention which resulted in injury or damage to the ship, the crew, all persons and objects on board, as well as its owner and every person involved or interested in its operations. ${ }^{96}$

In other words, this second claim by the Netherlands was considered by the Tribunal as merely concerning the scope of the Netherlands' standing as flag State, which was extended to include also all persons falling within the shipas-a-unit concept. ${ }^{97} \mathrm{~A}$ difference stance was instead taken by the Netherlands with respect to alternative claim of diplomatic protection on behalf of two Dutch nationals on board the Arctic Sunrise for the injuries suffered by these nationals caused by the breach of the same individual rights allegedly violated by Russia. This standing was indeed considered by the Netherlands to be subject, in principle, to the exhaustion of local remedies rule and nationality of claims rule. ${ }^{98}$ However, the Tribunal finally acknowledged that, since it had already found that the Netherlands had standing in respect of all persons on

94 Memorial of the Kingdom of the Netherlands, para. 106.

95 The Arctic Sunrise Case (The Netherlands v. Russian Federation) (Provisional Measures) ITLOS Case No 22 (22 November 2013). For a discussion, M.T. Drenan, 'Gone Overboard: Why the Arctic Sunrise Case Signals an Over-Expansion of the Ship-As-A-Unit Concept in the Diplomatic Protection Context' (2014) 45 The California Western International Law Journal 109 .

96 Arctic Sunrise Arbitration, Award, para. 175: 'The Tribunal accepts that all persons on board the Arctic Sunrise at the relevant times are part of the unit of the ship and therefore fall under the exclusive jurisdiction of the Netherlands as flag State. The nationality of the individuals is not relevant. The Netherlands is not exercising diplomatic protection in the classic sense over all of the individuals on board; it can only do that with respect to the Dutch nationals on board. Rather, the Netherlands is acting in its capacity as the flag State of the Arctic Sunrise, with exclusive jurisdiction over the vessel within the EEZ of Russia'.

97 Ibid., para. 175 .

98 However, the Netherlands submitted that the local remedies rule was not required in the present case due to the absence of a jurisdictional connection between the injured persons and the allegedly responsible State. See Memorial of the Kingdom of the Netherlands, paras 111-114. 
board the Arctic Sunrise, it was unnecessary to consider separately the claim of diplomatic protection on behalf of the Netherlands' two nationals. ${ }^{99}$ Thus, it did not elaborate on the local remedies issue.

In so deciding, the Tribunal seemingly upheld the Netherlands' implicit contention that the local remedies rule does not have relevance when a flag State is acting also on behalf of the ship-as-a-unit. True, the Netherlands 'was not exercising diplomatic protection in the classic sense over all of the individuals on board' ${ }^{\prime 00}$ As also acknowledged by the ILC in the Commentary to Art. 18 DADP, the right of the flag State to seek redress in respect of the members of the ship's crew cannot be characterized as diplomatic protection when the bond of nationality between the flag State and all members of a ship's crew is lacking. ${ }^{101}$ Nevertheless, with specific regard to the local remedies rule, there is nothing in the works of the Commission that might suggest that, in principle, the rule is not applicable when a State brings a case on behalf of a ship-asa-unit. As seen, the applicability of the local remedies rule depends on the interplay between direct and indirect elements of a claim and not on the type of protection accorded by a State (diplomatic protection in the classic sense or protection based on the ship-as-a-unit concept). In other words, the protection accorded on the basis of the ship-as-a-unit doctrine does not constitute, in and of itself, an exception to the local remedies rule. ${ }^{102}$ Rather, cases where the doctrine is resorted to should trigger the presumption that the local remedies rule is in principle applicable, without prejudice to the applicability of possible exceptions to it.

That is the reason why in the Arctic Sunrise award the arbitral Tribunal should have considered more thoroughly the Netherlands' contention about

\footnotetext{
99 Arctic Sunrise Arbitration, Award, para. 179.

100 Ibid., para. 175.

101 GAOR 61st Session Supp 10, 91 (1). The ILC however admits that 'there is nevertheless a close resemblance between this type of protection and diplomatic protection'.

102 See contra A. Cannone, 'L'ordinanza del Tribunale internazionale del diritto del mare sulla vicenda della Enrica Lexie' 1150, referring to the Enrica Lexie case, who seems to conceive the protection to the ship-as-a-unit as a reason for excluding the applicability of the local remedies rule. In a similar fashion, see L. Condorelli, 'La protection diplomatique et l'évolution de son domaine d'application' (2003) 86 Riv. Dir. Int. 5, 24-25, commenting upon the Saiga (No. 2) judgment. A different opinion is also expressed by Drenan, 'Gone Overboard: Why the Arctic Sunrise Case Signals an Over-Expansion of the Ship-As-A-Unit Concept in the Diplomatic Protection Context' 129-130, who maintains that in the Arctic Sunrise case only the Russian crewmembers 'should have been forced to exhaust their remedies in domestic Russian courts before the Netherlands was permitted to espouse claims on their behalf at the international level'.
} 
the applicability of the local remedies rule to its claim of diplomatic protection, especially because the rights allegedly violated were the same for all claims of standing made by the Netherlands. The Tribunal, instead, simply took for granted the purely direct nature of all the claims advanced by the Applicant.

The fact that the 'ship-as-a-unit' doctrine does not automatically entail an exemption from the local remedies rule finds some support in the recent practice of unCLOS Tribunals. In the Duzgit Integrity award, the arbitral Tribunal acknowledged that " $\mathrm{w}]$ hile Malta has characterized its claim as one of diplomatic protection, it has also invoked its rights as a flag State under the Convention.'103 After being satisfied that the obligations allegedly violated were owed by São Tomé to Malta under the Convention, it then accepted, by resorting to the ship-as-a-unit concept, that Malta had standing to bring claims in respect of alleged violations of its rights under the Convention which resulted in damage to all private entities involved or interested in the vessel's operations, regardless their nationality. At this point, unlike the Arctic Sunrise decision, where the arbitral Tribunal supposed the nature exclusively direct of all the claims, the Duzgit Integrity Tribunal correctly held as follows:

Once determined that Malta has standing to bring the current claims under the Convention, in order to decide whether the requirement of exhaustion of local remedies is still to be met, it must be clarified whether Malta's claims are preponderantly for injury to its direct or indirect rights, namely, for injury to its rights as the flag State of the vessel in relation to damages incurred by it. 104

In other words, the Tribunal recognized that it was not enough for the Applicant to claim the breach of its own rights and/or resort to the 'ship-as-aunit' concept in order to escape from the local remedies rule. Rather, it had to determine which elements of injury to its direct or indirect rights were preponderant. ${ }^{105}$

103 Duzgit Integrity Arbitration, Award, para. 147.

104 Ibid., para. 151 (emphasis added).

105 It is worth recalling that this line of reasoning was also recently endorsed by the Respondent in the abovementioned $M / V N$ Norstar case. As clearly stated by Italy: 'One of the elements associating the two situations pertaining to the State of nationality in the field of diplomatic protection, on the one hand, and to the flag State of a ship when seeking redress for the injury suffered by 'the ship, everything on it and every person involved or interested in its operations', on the other, is their espousal nature. The claims put forward by the State of nationality or by the flag State under such circumstances are equally 'indirect' in nature. Accordingly, when a claim is lodged by the flag State, preponderantly, if 
As Art. 295 UNCLOS clearly indicates, the local remedies rule is meant to function within the law of the sea regime where international law so requires. The present article has examined how UNCLOS Part XV Tribunals approached objections of admissibility based on this provision and, more generally, how such tribunals attempted to answer the question of when the local remedies rule is in principle applicable in cases where private entities are involved in UNCLOS disputes. As seen, this question essentially concerns the scope of the local remedies rule and intersects with the broader problem of the applicability of such rule to mixed claims. Accordingly, in this article the relevant case law has been assessed through the lens of the present state of international law on the subject and the corresponding works of the ILC. From this point of view, the survey of UNCLOS Tribunals' practice on the issue has revealed a quite controversial and uncontrolled use of the argument based on the direct character of the claim because of an alleged violation of an UNCLOS provision formally giving rights to States. For the reasons stated above this approach is hardly convincing.

One might speculate why UNCLOs Tribunals keep on taking such an approach in addressing the issue of mixed claims in relation to the local remedies rule since the very first case where the question arose. A possible reason could lie in a strong reluctance of such tribunals to be engaged in an evaluation of the remedies available in domestic legal orders, which might turn out a rather difficult task for the international judge. However, a reason of this kind could not justify the presumption of the direct nature of all claims grounded on UNCLOS provisions conferring rights to States. It is hard to admit that the scope of application of the local remedies rule could be totally compressed for merely practical reasons. Such rule still remains an important principle of customary international law that ultimately rests on State sovereignty. ${ }^{106}$

not exclusively, to seek redress for the individuals involved in the operation of the ship, the local remedies rule applies on the same grounds as in a diplomatic protection case'. Cf. Written Observations and Submissions of the Republic of Italy to Observations and Submissions of the Republic of Panama, para. 98, quoting Saiga (No. 2) para. 106. See also, $M / V$ Norstar, Judgment, para. 235. In its judgment, however, the Tribunal did not take a stand on the issue.

106 As Judge Córdova put it in his Separate Opinion appended to the ICJ judgment in the Interhandel case, " $[\mathrm{t}]$ he main reason for its existence lies in the indispensable necessity to harmonize the international and the national jurisdictions - assuring in this way the respect due to the sovereign jurisdiction of States - by which nationals and foreigners have to abide and to the diplomatic protection of the Governments to which only foreigners are entitled. This harmony, this respect for the sovereignty of States is brought about 
Potentially, the case law of UNCLOS Tribunals could greatly contribute to shed light on the complicated issue of mixed claims in international dispute settlement. As seen, law of the sea disputes offer frequent occasions to deal with these kinds of claims and, even more than the ICJ, UNCLOS Tribunals are among inter-state tribunals that are constantly called to face them. However, in holding this questionable method when addressing mixed claims, such tribunals not only have missed an opportunity to add to the development of the law on the subject. By narrowing down one of the most traditional conditions of admissibility of cases, they also risk fuelling the arguments of an excessive 'expansion' of their jurisdiction. Recent cases have triggered a number of criticisms in this sense. ${ }^{107}$ Although relating to different set of procedural issues, the core argument that can be deduced from these criticisms is that in the case law of UNCLOS Tribunals there is an ongoing trend to overly stretch the conditions to resort to UNCLOS Part XV procedures. The approach towards the local remedies rule here analysed apparently falls within this trend. And the fact that such approach lacks in legal reasoning does not certainly contribute to the legitimacy of judicial bodies that follow it.

A change of course with respect to the applicability of the local remedies rule is thus called for. A more thorough enquiry by UNCLOS Tribunals to properly characterize disputes brought before them is needed so as not to add further to the impression that the preconditions of jurisdiction and admissibility are at complete disposal of the claimant parties or of UNCLOS Tribunals' unreasoned discretion.

\section{Acknowledgments}

The author would like to thank Professor Paolo Palchetti for his invaluable comments and suggestions.

by giving priority to the jurisdiction of the local courts of the State in cases of foreigners claiming against an act of its executive or legislative authorities. This priority, in turn, is assured only by means of the adherence to the principle of exhaustion of local remedies', ICJ Reports 1959, 45.

107 Talmon, "The Chagos Marine Protected Area Arbitration: Expansion of the Jurisdiction of unclos Part Xv Courts and Tribunals'; P. Tzeng, 'Supplemental Jurisdiction under UNCLOS' (2016) 38 Houston Journal of International Law 499; N. Klein, 'Expansions and Restrictions in the UnCLos Dispute Settlement Regime: Lessons from Recent Decisions' (2016) 15 Chinese Journal of International Law 403. 